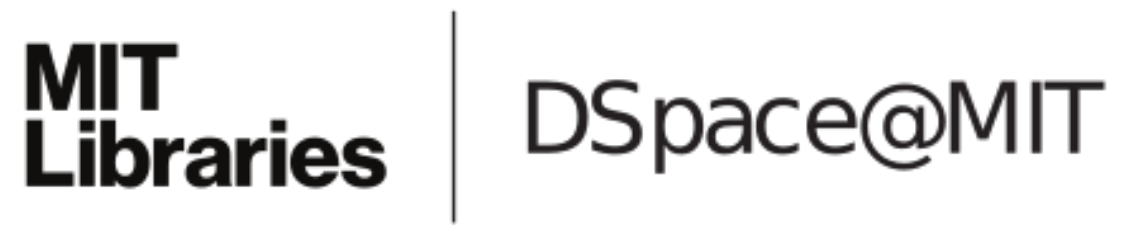

\author{
MIT Open Access Articles
}

Record-Setting Sorbents for Reversible Water Uptake by Systematic Anion Exchanges in Metal-Organic Frameworks

The MIT Faculty has made this article openly available. Please share how this access benefits you. Your story matters.

Citation: Rieth, Adam J. et al. "Record-Setting Sorbents for Reversible Water Uptake by Systematic Anion Exchanges in Metal-Organic Frameworks." Journal of the American Chemical Society 141, 35 (August 2019): 13858-13866 (c) 2019 American Chemical Society

As Published: http://dx.doi.org/10.1021/jacs.9b06246

Publisher: American Chemical Society (ACS)

Persistent URL: https://hdl.handle.net/1721.1/124981

Version: Final published version: final published article, as it appeared in a journal, conference proceedings, or other formally published context

Terms of use: Creative Commons Attribution-NonCommercial-NoDerivs License 


\title{
Record-Setting Sorbents for Reversible Water Uptake by Systematic Anion Exchanges in Metal-Organic Frameworks
}

\author{
Adam J. Rieth, ${ }^{\dagger}$ Ashley M. Wright, ${ }^{\dagger}$ (๖) Grigorii Skorupskii, ${ }^{\dagger}$ Jenna L. Mancuso, \\ Christopher H. Hendon, ${ }^{\dagger}$ and Mircea Dinca ${ }^{*}+\dagger$ \\ ${ }^{\dagger}$ Department of Chemistry, Massachusetts Institute of Technology, 77 Massachusetts Avenue, Cambridge, Massachusetts 02139,
United States
${ }^{\ddagger}$ Materials Science Institute, Department of Chemistry and Biochemistry, University of Oregon, Eugene, Oregon 97403, United
States
}

Supporting Information

ABSTRACT: The reversible capture of water vapor at low humidity can enable transformative applications such as atmospheric water harvesting and heat transfer that uses water as a refrigerant, replacing environmentally detrimental hydro- and chloro-fluorocarbons. The driving force for these applications is governed by the relative humidity at which the pores of a porous material fill with water. Here, we demonstrate modulation of the onset of pore-filling in a family of metal-organic frameworks with record water sorption capacities by employing anion exchange. Unexpectedly, the replacement of the structural bridging $\mathrm{Cl}^{-}$with the

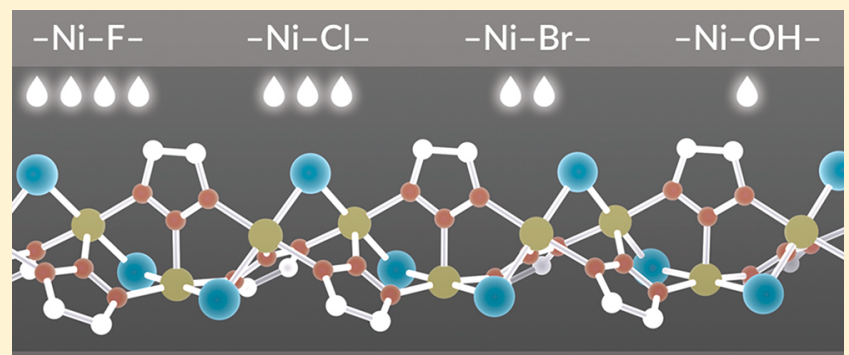

tunable water sorption in metal-organic frameworks more hydrophilic anions $\mathrm{F}^{-}$and $\mathrm{OH}^{-}$does not induce porefilling at lower relative humidity, whereas the introduction of the larger $\mathrm{Br}^{-}$results in a substantial shift toward lower relative humidity. We rationalize these results in terms of pore size modifications as well as the water hydrogen bonding structure based on detailed infrared spectroscopic measurements. Fundamentally, our data suggest that, in the presence of strong nucleation sites, the thermodynamic favorability of water pore-filling depends more strongly on the pore diameter and the interface between water in the center of the pore and water bound to the pore walls than the hydrophilicity of the pore wall itself. On the basis of these results, we report two materials that exhibit record water uptake capacities in their respective humidity regions and extended stability over 400 water adsorption-desorption cycles.

\section{INTRODUCTION}

The capture of water vapor at low relative humidity $(0-40 \%$ $\mathrm{RH})$ can be used to drive heat transfer, ${ }^{1-8}$ to trap atmospheric water vapor, ${ }^{2,9-13}$ or for dehumidification. ${ }^{14-18}$ Recent advancements in the design of porous materials for these applications have moved next-generation water sorbents closer to applicability, $2,4,13,15,16$ but methods to precisely control the hydrophilicity of a sorbent are still needed. Complicating sorbent design, the mechanism of water uptake at low relative humidity remains incompletely understood due to the complex nature of the water phase-change process as well as the difficulty of accurately simulating the properties of water. ${ }^{19,20}$

In order to achieve maximum thermal efficiency, a porous material should have a high capacity for water and should adsorb water reversibly and in a stepwise fashion at a precise $\mathrm{RH}^{21}$ Additionally, although nontrivial, it is highly desirable to have synthetic control over the position (\% RH) of the water uptake step. $^{22-24}$ The $\% \mathrm{RH}$ whereupon a pore fills with water determines the driving force for heat transfer and, concomitantly, the temperature required to release water from the sorbent: more hydrophilic sorbents are capable of creating greater temperature gradients but also require more energy to cycle back to the dry state. ${ }^{21}$ In the case of atmospheric water capture, the \% $\mathrm{RH}$ of the uptake step determines the applicable climatic region. ${ }^{11,13}$

Outside the confines of a porous material, water condensation occurs at $100 \% \mathrm{RH}$. In porous materials, water begins to occupy the voids at lower $\mathrm{RH}$ with decreasing pore diameter, ${ }^{25}$ and complete saturation occurs near $0 \% \mathrm{RH}$ in some cases. ${ }^{1,26,27}$ Additionally, the hydrophilicity of the pore interior, modifiable via ligand functionalization, ${ }^{23,24,28}$ cation exchange, ${ }^{22}$ as well as exchange of supporting ligands, ${ }^{29}$ plays a role in determining the $\mathrm{RH}$ at which the pore will fill. These empirical design rules have guided the development of sorbents with impressive performance, even though the underlying hydrogen bonding structure of water in confined pores, which undoubtedly influences the position of the pore filling step, remains unclear. Indeed, water in confinement and along interfaces can have properties very different from that of bulk water, as the pore structure or interface itself impose restrictions on the complex hydrogen bonding structures. ${ }^{30,31}$

Received: June 12, 2019

Published: August 9, 2019 

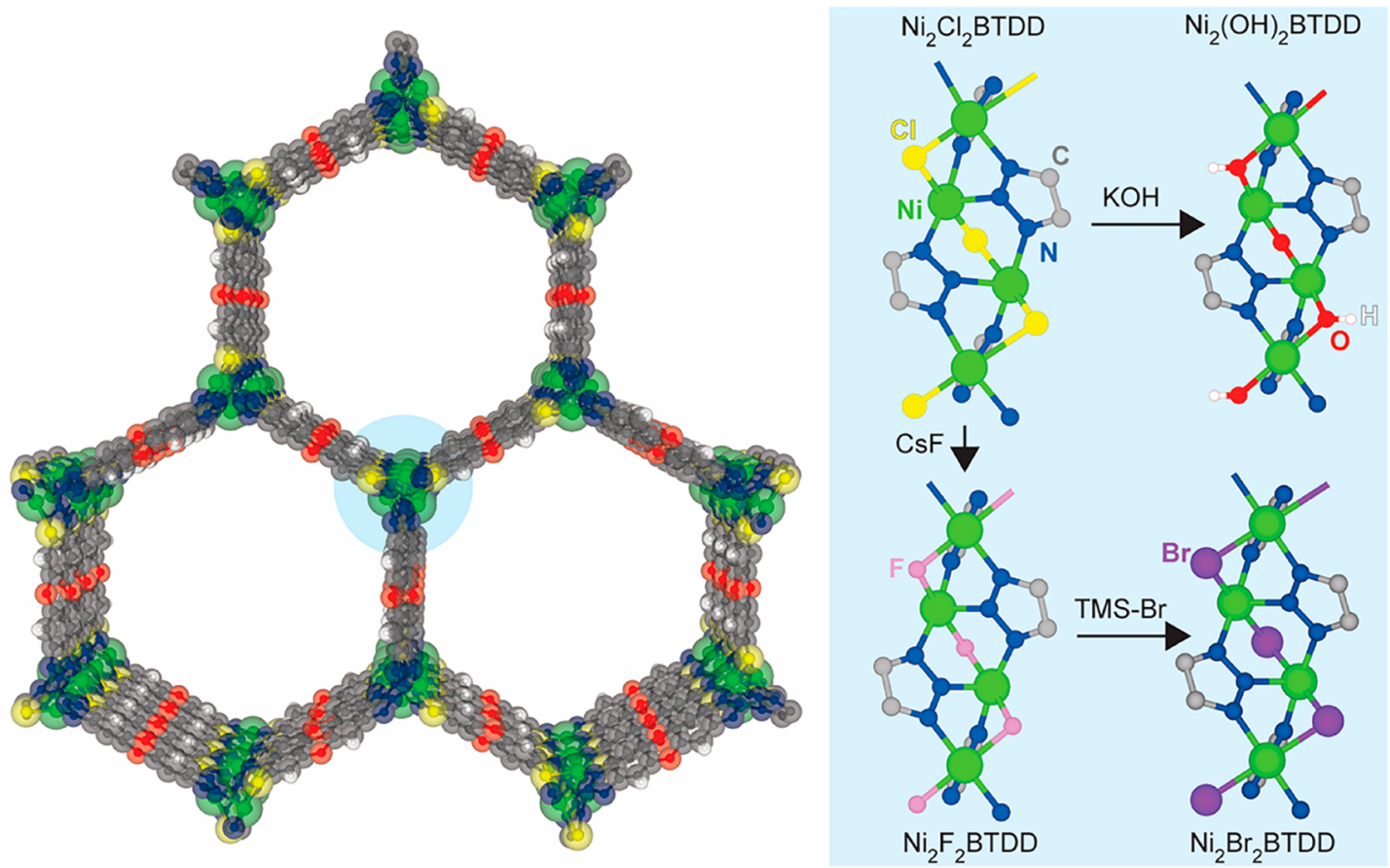

Figure 1. Structure of $\mathrm{Ni}_{2} \mathrm{X}_{2} \mathrm{BTDD}(\mathrm{X}=\mathrm{Cl}, \mathrm{F}, \mathrm{Br}, \mathrm{OH})$. Left: View parallel to the $c$ axis. Right: View of anion-exchanged SBUs perpendicular to the $c$ axis and synthetic pathways.
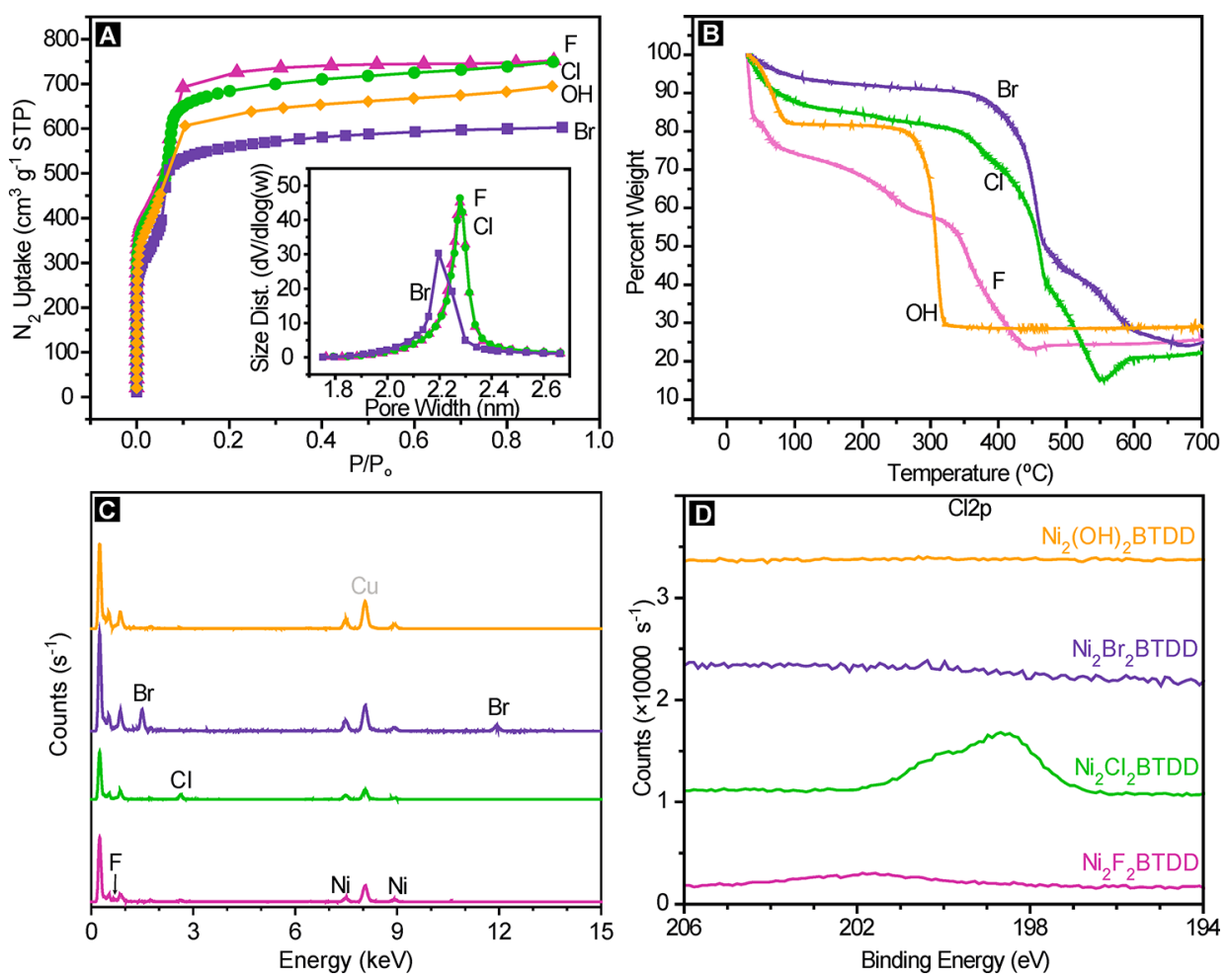

Figure 2. (A) Nitrogen isotherms at $77 \mathrm{~K}$ for $\mathrm{Ni}_{2} \mathrm{X}_{2} \mathrm{BTDD}$. Inset: Barrett-Joyner-Halenda $(\mathrm{BJH})^{39}$ pore size distribution calculated using the Kruk-Jaroniec-Sayari ${ }^{40}$ correction for hexagonal pores from the $77 \mathrm{~K} \mathrm{~N}_{2}$ adsorption isotherms. (B) Thermogravimetric analysis of $\mathrm{Ni}_{2} \mathrm{X}_{2} \mathrm{BTDD}$. (C) Energy-dispersive $\mathrm{X}$-ray spectra (EDS) for $\mathrm{Ni}_{2} \mathrm{X}_{2} \mathrm{BTDD}$. (D) X-ray photoelectron spectroscopy (XPS) at the $\mathrm{Cl} 2 \mathrm{p}$ energy for $\mathrm{Ni}_{2} \mathrm{X}_{2} \mathrm{BTDD}$.

Metal-organic frameworks (MOFs) provide an ideal platform for interrogating the hydrogen bonding structure of confined water because their modular nature allows for tuning of the pore size, metal ion, and hydrophilicity without altering the overall framework topology. ${ }^{32}$ In addition to precisely controlling the water uptake step position, the stability of water sorbents is also of paramount importance because applications for water harvesting or heat transfer will require active materials capable of undergoing thousands of adsorption cycles. This is an important practical consideration that only rarely is addressed in the academic literature. ${ }^{33}$ 


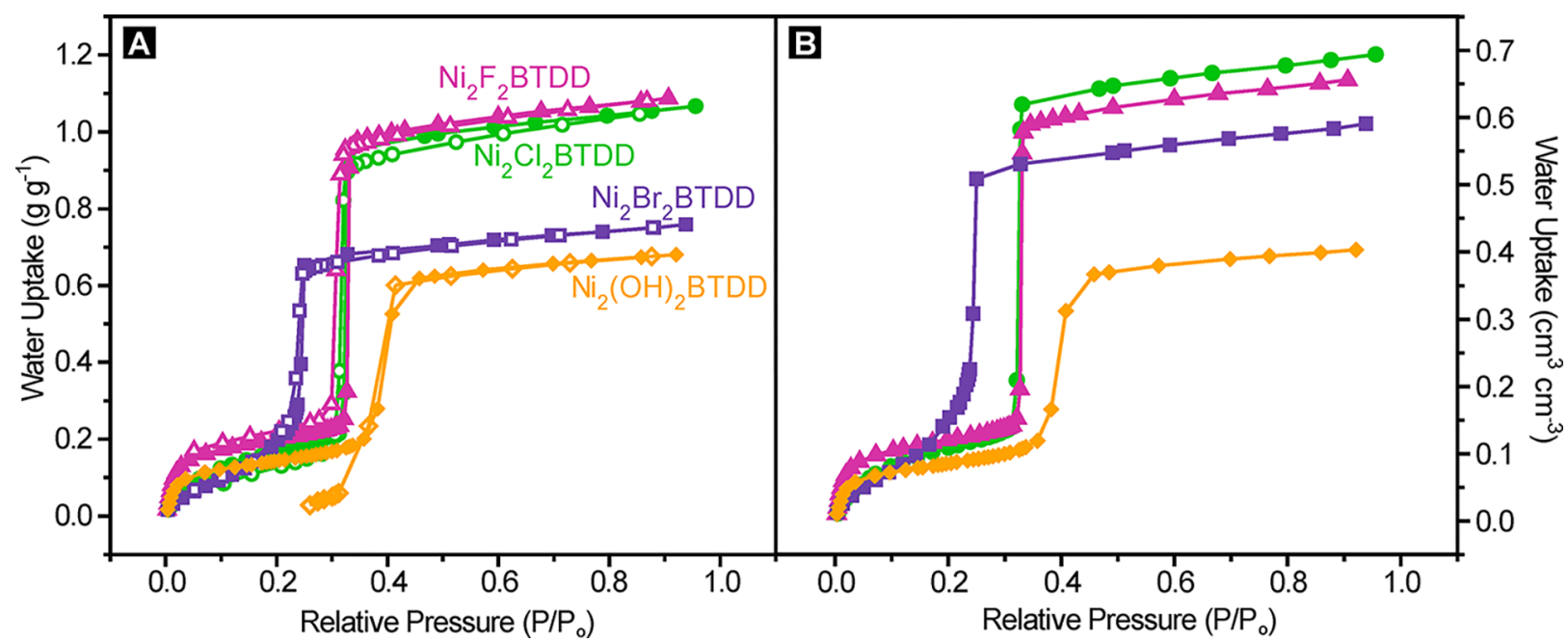

Figure 3. (A) Water vapor adsorption (closed symbols) and desorption (open symbols) isotherms of $\mathrm{Ni}_{2} \mathrm{Br}_{2} \mathrm{BTDD}, \mathrm{Ni}_{2} \mathrm{Cl}_{2} \mathrm{BTDD}$, $\mathrm{Ni}_{2} \mathrm{~F}_{0.83} \mathrm{Cl}_{0.17} \mathrm{BTDD}$, and $\mathrm{Ni}_{2}(\mathrm{OH})_{2} \mathrm{BTDD}$ measured at $25^{\circ} \mathrm{C}$. (B) Adsorption isotherms converted to volumetric units using the material density.

Table 1. Unit Cell and Select Crystallographic Parameters Determined by Rietveld Refinement or by DFT ${ }^{a}$

\begin{tabular}{|cccccc|} 
Rietveld & $a, b$ & $c$ & $\mathrm{Ni}-\mathrm{N}_{1}$ & $\mathrm{Ni}-\mathrm{X}$ & $\mathrm{Ni}-\mathrm{X}-\mathrm{Ni}$ \\
$\mathrm{Ni}_{2} \mathrm{~F}_{0.83} \mathrm{Cl}_{0.17} \mathrm{BTDD}$ & $38.6092(5)$ & $8.0929(1)$ & $2.02(2)$ & $2.06(2)$ & $112.2(2)^{\circ}$ \\
$\mathrm{Ni}_{2} \mathrm{Cl}_{2} \mathrm{BTDD}$ & $38.5282(5)$ & $8.1888(1)$ & $2.04(2)$ & $2.384(3)$ & $92.4(2)^{\circ}$ \\
$\mathrm{Ni}_{2} \mathrm{Br}_{2} \mathrm{BTDD}$ & $38.4250(2)$ & $8.2077(1)$ & $2.03(1)$ & $2.503(1)$ & $87.4(2)^{\circ}$ \\
\hline $\mathrm{DFT}$ & $a, b$ & $c$ & $\mathrm{Ni}-\mathrm{N}_{1}$ & $\mathrm{Ni}-\mathrm{X}$ & $\mathrm{Ni}-\mathrm{X}-\mathrm{Ni}$ \\
\hline $\mathrm{Ni}_{2} \mathrm{~F}_{2} \mathrm{BTDD}$ & 38.846 & 7.663 & 1.91 & 2.02 & $100.4^{\circ}$ \\
$\mathrm{Ni}_{2} \mathrm{Cl}_{2} \mathrm{BTDD}$ & 38.507 & 7.932 & 1.92 & 2.33 & $87.9^{\circ}$ \\
$\mathrm{Ni}_{2} \mathrm{Br}_{2} \mathrm{BTDD}$ & 38.364 & 8.009 & 1.92 & 2.46 & $83.8^{\circ}$ \\
$\mathrm{Ni}_{2}(\mathrm{OH})_{2} \mathrm{BTDD}$ & 38.897 & 7.807 & 1.92 & 1.99 & $104.0^{\circ}$
\end{tabular}

${ }^{a}$ Distances are in $\AA ; \mathrm{N}_{1}$ is the central triazolate nitrogen.

Recently, we reported a MOF that captures record quantities of water in the humidity region relevant for many applications. ${ }^{2}$ The water uptake capacity in this material is optimized: because the pore size is at the "critical diameter" ${ }^{25,34}$ for water capillary condensation during porefilling, its high water capacity is completely reversible, without appreciable hysteresis. This minimizes the energy input required for cycling between the hydrated and dry states. The champion material, synthesized from the ligand bis $(1 \mathrm{H}$ 1,2,3-triazolo[4,5- $b],\left[4^{\prime}, 5^{\prime}-\mathrm{i}\right]$ ) dibenzo[1,4]dioxin ( $\left.\mathrm{H}_{2} \mathrm{BTDD}\right)$ and $\mathrm{CoCl}_{2} \cdot 6 \mathrm{H}_{2} \mathrm{O}$, exhibits a capacity of nearly $1 \mathrm{~g}$ of $\mathrm{H}_{2} \mathrm{O}$ $\mathrm{g}^{-1}$ of $\mathrm{MOF}^{2}$ Here we report that the $\mathrm{Ni}^{2+}$ variant, $\mathrm{Ni}_{2} \mathrm{Cl}_{2} \mathrm{BTDD}$, can be synthesized with greater crystallinity and porosity than previously possible, enabling it to match the capacity of the $\mathrm{Co}^{2+}$ material. We further show through extended cycling experiments that the decreased lability of $\mathrm{Ni}^{2+35}$ leads to excellent long-term stability well beyond that of the $\mathrm{Co}^{2+}$ analogue. Finally, we demonstrate that $\mathrm{Ni}_{2} \mathrm{Cl}_{2} \mathrm{BTDD}$ undergoes facile anion exchange whereby hydroxide, fluoride, or bromide anions isostructurally replace native chloride ligands (Figure 1). These anion metathesis manipulations modulate hydrogen bonding interactions between water and the pore wall, resulting in stark differences in water uptake at low $\mathrm{RH}$ for the different anion-containing MOFs. Fundamentally, these structural perturbations provide a platform to investigate the hydrogen-bonding structure of confined and interfacial water during the pore-filling process by diffuse reflectance infrared Fourier transform spectroscopy (DRIFTS). Beyond tuning the hydrophilicity, the series of halogens modulates the pore size of the respective MOFs in a nonintuitive way, with the larger bromide yielding the shortest $a$ and $b$ cell parameters. This subtle variation leads to critical changes in the hydrogen bonding structure of water within the pore. Consequently, pore filling occurs at substantially lower relative humidity $(\mathrm{RH})$ in $\mathrm{Ni}_{2} \mathrm{Br}_{2} \mathrm{BTDD}$. This is counterintuitive because below 5\% RH the bromide derivative is the least hydrophilic. Importantly, the introduction of bromide maintains exceptional water stability, with negligible loss of capacity after 400 adsorption cycles. These systematic synthetic variations further our fundamental understanding of water in confinement and provide a promising new adsorbent with record water capacity at low $(<25 \%) \mathrm{RH}$ and excellent long-term stability.

\section{RESULTS AND DISCUSSION}

Highly crystalline $\mathrm{Ni}_{2} \mathrm{Cl}_{2} \mathrm{BTDD}$ can be accessed from $\mathrm{H}_{2} \mathrm{BTDD}$ and $\mathrm{NiCl}_{2} \cdot 6 \mathrm{H}_{2} \mathrm{O}$ under solvothermal conditions in a mixture of 100:100:64 DMF:MeOH: $\mathrm{HCl}_{\mathrm{aq}}$ at $100{ }^{\circ} \mathrm{C}$. A significantly greater acid concentration and higher temperatures than those used for isostructural materials with other metal cations such as $\mathrm{Co}^{2+}, \mathrm{Mn}^{2+}, \mathrm{Fe}^{2+}$, or $\mathrm{Cu}^{2+}$ allow for increased crystallinity with the more inert $\mathrm{Ni}^{2+}$. By powder $\mathrm{X}$ ray diffraction (PXRD) as well as a Brunauer-Emmet-Teller (BET) surface area analysis from a nitrogen isotherm at $77 \mathrm{~K}$, the new synthesis of $\mathrm{Ni}_{2} \mathrm{Cl}_{2} \mathrm{BTDD}$ results in improvements in crystallinity as well as porosity over previous reports of this material, with the improved MOF exhibiting a BET area of $1837 \mathrm{~m}^{2} \mathrm{~g}^{-1}$, in line with those of the previously reported Co, 

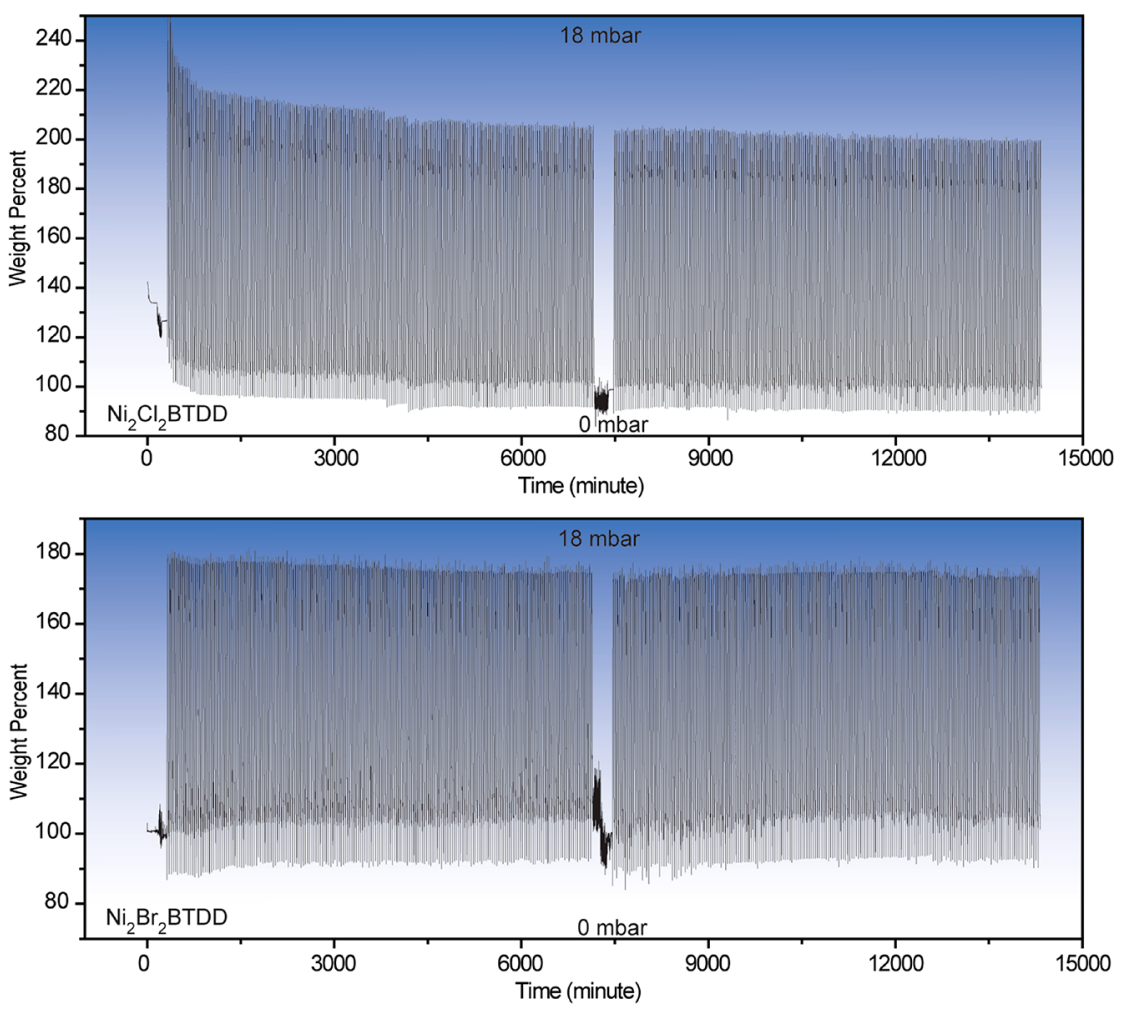

Figure 4. 400 cycles of water uptake for $\mathrm{Ni}_{2} \mathrm{Cl}_{2} \mathrm{BTDD}$ (top) and $\mathrm{Ni}_{2} \mathrm{Br}_{2} \mathrm{BTDD}$ (bottom), switching from 0 mbar of $\mathrm{H}_{2} \mathrm{O}$ to $18 \mathrm{mbar}$ of $\mathrm{H}_{2} \mathrm{O}$ approximately every $15 \mathrm{~min}$, with a variable phase delay period to switch between pressures. After 200 cycles, each sample was reactivated at $70{ }^{\circ} \mathrm{C}$ for $3 \mathrm{~h}$.

$\mathrm{Mn}$, and $\mathrm{Cu}$ analogues (Figure $2 \mathrm{~A}){ }^{36}$ Rietveld refinement of high-resolution synchrotron PXRD data provides the first experimental crystal structure of this material, confirming a hexagonal space group with unit cell parameters $a=b=$ 38.5282(5) $\AA, c=8.1888(1) \AA$ (Figure S9.1). Accompanying the increased $\mathrm{BET}$ surface area is a significantly larger water uptake capacity at $25^{\circ} \mathrm{C}$ of $1.07 \mathrm{~g} \mathrm{~g}^{-1}$ (Figure 3), an over $40 \%$ improvement over the value reported previously for this material. ${ }^{2}$ This capacity is the highest reported for materials with $\alpha$ (defined as the $\% \mathrm{RH}$ at which half of the total uptake is reached) below $35 \% \mathrm{RH}$. Importantly, $\mathrm{Ni}_{2} \mathrm{Cl}_{2} \mathrm{BTDD}$ adsorbs water reversibly, that is, without hysteresis. As expected due to the greater inertness of $\mathrm{Ni}^{2+}$ relative to $\mathrm{Co}^{2+}, 35$ extended pressure-swing cycling revealed remarkable stability for $\mathrm{Ni}_{2} \mathrm{Cl}_{2} \mathrm{BTDD}$, which maintains $98 \%$ of its original water uptake capacity by weight (wt \%) after 400 cycles (Figure 4A), with negligible changes in crystallinity or $\mathrm{N}_{2}$ uptake after water cycling (Figures S3.1 and S4.1). In contrast, the uptake capacity of $\mathrm{Co}_{2} \mathrm{Cl}_{2} \mathrm{BTDD}$ decays by $6.3 \%$ over 30 cycles, with no clear plateau in the decay rate. ${ }^{2}$ These data further reinforce the concept of using inert metal ions to enhance framework chemical stability. ${ }^{37}$

Anion-Exchanged Variants of $\mathrm{Ni}_{2} \mathrm{Cl}_{2} \mathrm{BTDD}$. Inspired by a recent report of anion exchange to replace the original $\mathrm{Cl}^{-}$by $\mathrm{OH}^{-}$in structurally related materials, ${ }^{38}$ we reasoned that the introduction of bridging anions such as $\mathrm{OH}^{-}$and $\mathrm{F}^{-}$, which could provide hydrogen bonding interactions for water, should create a more hydrophilic pore environment that would induce pore filling at lower $\mathrm{RH}$. Soaking $\mathrm{Ni}_{2} \mathrm{Cl}_{2} \mathrm{BTDD}$ in a dilute aqueous solution of $\mathrm{KOH}$ yielded a crystalline material with undetectable chloride according to energy-dispersive X-ray spectroscopy (EDS) and X-ray photoelectron spectroscopy
(XPS) (Figure 2C and D). Infrared spectroscopy (IR) of the hydroxide-exchanged material, $\mathrm{Ni}_{2}(\mathrm{OH})_{2} \mathrm{BTDD}$, kept under $\mathrm{N}_{2}$ upon activation revealed a hydroxide $\mathrm{O}-\mathrm{H}$ stretching band at $3645 \mathrm{~cm}^{-1}$ (Figure 5A). The BET surface area of $1792 \mathrm{~m}^{2}$ $\mathrm{g}^{-1}$ is within $3 \%$ of that of $\mathrm{Ni}_{2} \mathrm{Cl}_{2} \mathrm{BTDD}$, although $\mathrm{Ni}_{2}(\mathrm{OH})_{2} \mathrm{BTDD}$ exhibits drastic mass loss in the thermogravimetric analysis (TGA) near $250{ }^{\circ} \mathrm{C}$ as compared to $350{ }^{\circ} \mathrm{C}$ for the parent chloride material (Figure $2 \mathrm{~A}$ and $\mathrm{B}$ ).

As expected, a water isotherm for $\mathrm{Ni}_{2}(\mathrm{OH})_{2} \mathrm{BTDD}$ reveals greater initial hydrophilicity, with increased water uptake before 5\% RH. However, after 5\% RH, the hydroxide material exhibits a decreased water capacity compared with the chloride analogue. Moreover, the $\mathrm{OH}^{-}$material has a greatly reduced uptake step in the pore-filling region (Figures 3 and S10.1) and exhibits an irreversible desorption isotherm, along with a steep decline in capacity upon cycling beyond the initial cycle (Figure S7.1). Although PXRD demonstrated that at least some of the sample maintains crystallinity (Figure S3.2) upon water exposure, a $\mathrm{N}_{2}$ isotherm revealed significantly reduced pore volume and a decreased BET area of $980 \mathrm{~m}^{2} \mathrm{~g}^{-1}$ for $\mathrm{Ni}_{2}(\mathrm{OH})_{2} \mathrm{BTDD}$ (Figure S4.2).

An alternative path toward increasing framework-water hydrogen bonding is the exchange of $\mathrm{Cl}^{-}$by $\mathrm{F}^{-}$. Because of its reduced basicity compared to $\mathrm{OH}^{-}, \mathrm{F}^{-}$may disfavor proton transfer from guest water molecules, which in the case of $\mathrm{Ni}_{2}(\mathrm{OH})_{2}$ BTDD may lead to its ultimate collapse. Soaking assynthesized $\mathrm{Ni}_{2} \mathrm{Cl}_{2} \mathrm{BTDD}$ in a DMF solution of excess CsF for $12 \mathrm{~h}$ results in nearly quantitative exchange of $\mathrm{Cl}^{-}$for $\mathrm{F}^{-}$, as verified by EDS and XPS analyses (Figures 2C,D, S5.1, and $\mathrm{S} 5.2$ ). The precise $\mathrm{F}: \mathrm{Cl}$ ratio was determined by treating the fluoride-exchanged sample with trimethylsilyl bromide (TMS$\mathrm{Br}$ ), which produces quantitatively the bromide-exchanged 


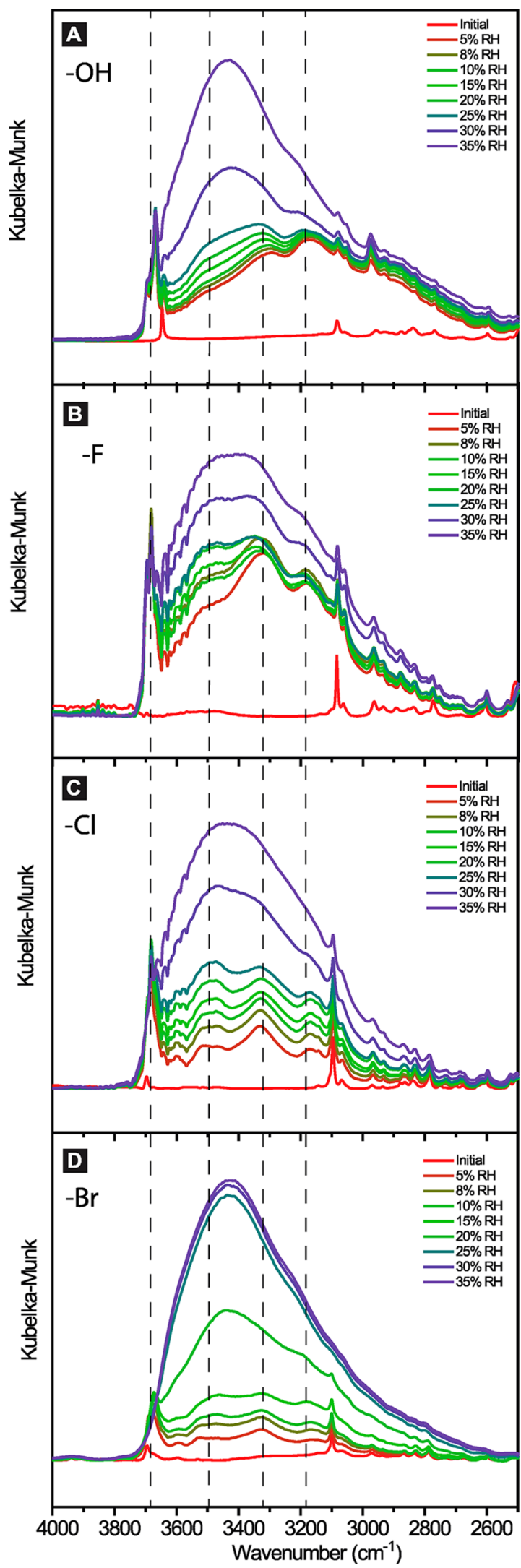

Figure 5. Diffuse reflectance infrared spectroscopy (DRIFTS) focusing on the water $\mathrm{O}-\mathrm{H}$ stretching region for $\mathrm{Ni}_{2}(\mathrm{OH})_{2} \mathrm{BTDD}$ (A), $\mathrm{Ni}_{2} \mathrm{~F}_{0.83} \mathrm{Cl}_{0.17}$ BTDD (B), $\mathrm{Ni}_{2} \mathrm{Cl}_{2} \mathrm{BTDD}$ (C), and $\mathrm{Ni}_{2} \mathrm{Br}_{2} \mathrm{BTDD}$ (D) as a function of relative humidity (\% RH). Full IR spectra are in Figures S6.1-S6.4. Dashed lines are guides for the eye for the peak maxima of four major regions of the $\mathrm{OH}$ stretch.
MOF, $\mathrm{Ni}_{2} \mathrm{Br}_{2} \mathrm{BTDD}$, and soluble trimethylsilyl-fluoride (TMSF) and trimethylsilyl-chloride (TMS-Cl). Nuclear magnetic resonance (NMR) analysis of the filtrate revealed a TMS$\mathrm{F}$ :TMS-Cl ratio of 1.0:0.2 and thus the formula $\mathrm{Ni}_{2} \mathrm{~F}_{0.83} \mathrm{Cl}_{0.17} \mathrm{BTDD}$ for the fluoride-exchanged MOF (Figure S8.1). After restraining the $\mathrm{F}: \mathrm{Cl}$ ratio to within $2 \%$ of the NMR-determined value, Rietveld refinement of high-resolution synchrotron PXRD data also converged to $19 \%$ chloride and $81 \%$ fluoride occupancy for the fluoride-exchanged MOF (Figure S9.2). The BET surface area, as measured by a $77 \mathrm{~K}$ $\mathrm{N}_{2}$ isotherm, is $1770 \mathrm{~m}^{2} \mathrm{~g}^{-1}$, which is essentially identical to that of the hydroxide analogue (Figure 2A), whereas TGA indicates substantial mass loss around $200{ }^{\circ} \mathrm{C}$ (Figure 2B).

$\mathrm{Ni}_{2} \mathrm{~F}_{0.83} \mathrm{Cl}_{0.17} \mathrm{BTDD}$ indeed adsorbs substantially more water than $\mathrm{Ni}_{2} \mathrm{Cl}_{2} \mathrm{BTDD}$ at low $\mathrm{RH}$, below the pore-filling pressure. In particular, even at $2 \% \mathrm{RH}, \mathrm{Ni}_{2} \mathrm{~F}_{0.83} \mathrm{Cl}_{0.17} \mathrm{BTDD}$ captures 1.3 molecules of water per $\mathrm{Ni}^{2+}$ open coordination site, whereas $\mathrm{Ni}_{2} \mathrm{Cl}_{2} \mathrm{BTDD}$ captures only $0.6 \mathrm{H}_{2} \mathrm{O}$ per $\mathrm{Ni}^{2+}$ under the same conditions (Figure S10.1). We expected that this increased water uptake at low RH would induce the pore-filling step to occur at a lower vapor pressure. Interestingly, this is not the case, and pore-filling step occurs at almost exactly the same relative humidity, $32 \% \mathrm{RH}$, in the fluoride-exchanged material as in the parent chloride analogue (Figure 3). Less encouragingly, even though $\mathrm{Ni}_{2} \mathrm{~F}_{0.83} \mathrm{Cl}_{0.17}$ BTDD largely retains its porosity (Figure S4.3), PXRD reveals the emergence of a broad new peak around $2 \theta=7^{\circ}$, indicating partial amorphization (Figure S3.4), and a water cycling experiment indicates rapid decline in capacity after the initial cycle (Figure S7.2).

Close inspection of the structural parameters of the anionexchanged MOFs revealed a surprise expansion of the $a, b$ parameters from 38.5282(5) $\AA$ for $\mathrm{Ni}_{2} \mathrm{Cl}_{2} \mathrm{BTDD}$ to 38.6092(5) $\AA$ upon fluoride exchange, despite the expected contraction of the $c$ parameter upon replacing the larger $\mathrm{Cl}^{-}$with $\mathrm{F}^{-}$(Table 1). Computational optimization of the two idealized, fully exchanged fluoride and chloride structures by density functional theory (DFT) confirmed this unexpected trend and further predicted that the bromide-exchanged analogue, $\mathrm{Ni}_{2} \mathrm{Br}_{2} \mathrm{BTDD}$, should have an even narrower pore due to a further reduction of $a$ and $b$ by at least $0.1 \AA$ relative to $\mathrm{Ni}_{2} \mathrm{Cl}_{2}$ BTDD (Table 1). Furthermore, owing to its larger covalent radius, $\mathrm{Br}^{-}$should protrude into the pore to a greater extent than any of the other anions, further narrowing the pore diameter and potentially leading to water uptake at lower $\mathrm{RH}$ due to increased confinement.

Although accessing $\mathrm{Ni}_{2} \mathrm{Br}_{2} \mathrm{BTDD}$ directly from $\mathrm{Ni}_{2} \mathrm{Cl}_{2} \mathrm{BTDD}$ proved challenging, treatment of the fluorideexchanged material with a small excess of TMS-Br led to quantitative formation of $\mathrm{Ni}_{2} \mathrm{Br}_{2} \mathrm{BTDD}$ and complete loss of $\mathrm{Cl}^{-}$and $\mathrm{F}^{-}$. EDS and XPS analysis of this material revealed prominent $\mathrm{Br}$ signals and undetectable signals for other halogens (Figures 2C,D and S5.3). Rietveld refinement of a PXRD pattern of $\mathrm{Ni}_{2} \mathrm{Br}_{2} \mathrm{BTDD}$ (Figure S9.3) revealed the predicted contraction of the $a, b$ parameters to $38.4250(2)$, in excellent agreement with the DFT calculations (Table 1). The BET surface area of the $\mathrm{Br}$ material is $1467 \mathrm{~m}^{2} \mathrm{~g}^{-1}$ (Figure 2A). A BET area of $1530 \mathrm{~m}^{2} \mathrm{~g}^{-1}$ is reasonable considering the 1.2 times greater molecular weight of the $\mathrm{Br}$ MOF versus the $\mathrm{Cl}$ material. Pore size distribution analysis of the $\mathrm{N}_{2}$ adsorption isotherm reveals a small but significant reduction of the accessible pore diameter in $\mathrm{Ni}_{2} \mathrm{Br}_{2} \mathrm{BTDD}$, from $2.3 \mathrm{~nm}$ in the $\mathrm{Cl}$ and $\mathrm{F}$ materials to $2.2 \mathrm{~nm}$ in the $\mathrm{Br}$ material (Figure $2 \mathrm{~A}$ ). 


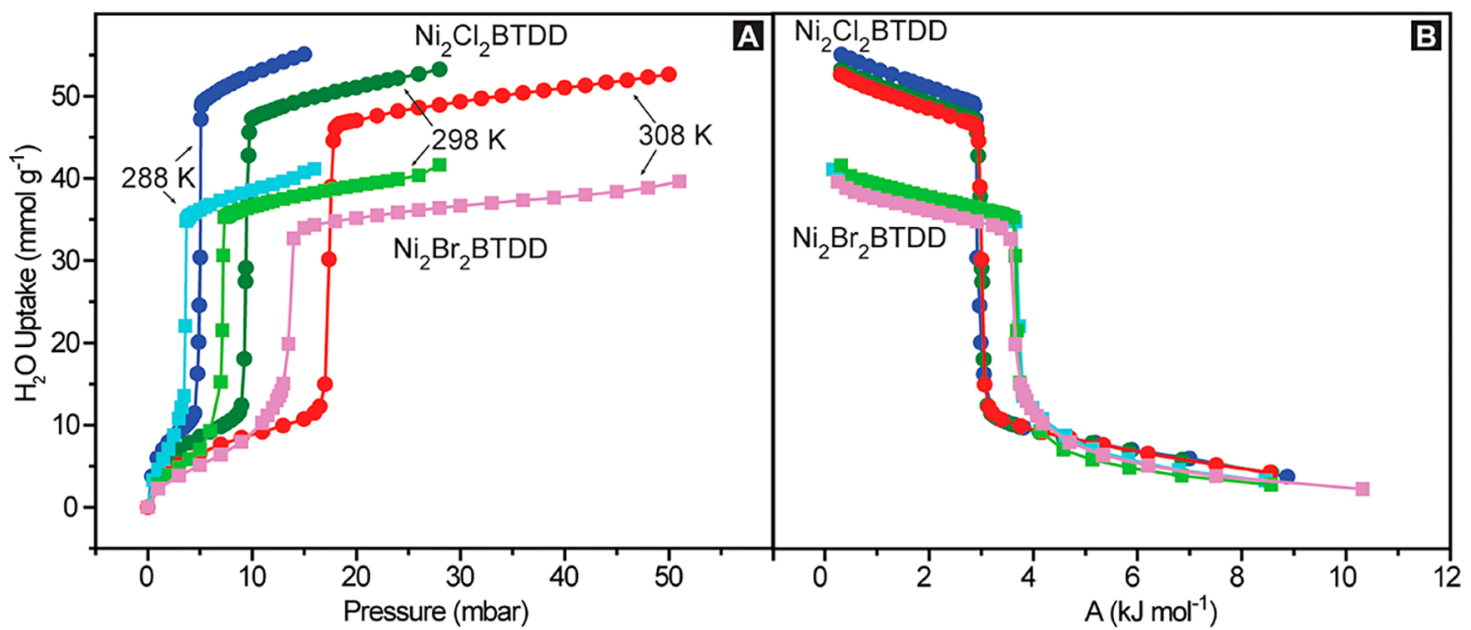

Figure 6. (A) Variable temperature water isotherms, obtained via the gravimetric method, for $\mathrm{Ni}_{2} \mathrm{Cl}_{2} \mathrm{BTDD}$ (blue $288 \mathrm{~K}$, green $298 \mathrm{~K}$, red $308 \mathrm{~K}$ ) and $\mathrm{Ni}_{2} \mathrm{Br}_{2} \mathrm{BTDD}$ (light blue $288 \mathrm{~K}$, light green $298 \mathrm{~K}$, pink $308 \mathrm{~K}$ ). (B) Characteristic curves for $\mathrm{Ni}_{2} \mathrm{Cl}_{2} \mathrm{BTDD}$ and $\mathrm{Ni}_{2} \mathrm{Br}_{2} \mathrm{BTDD}$ calculated from the water isotherms.

Indeed, relatively small variations in accessible pore diameters induce large shifts in the $\% \mathrm{RH}$ where water sorption occurs: isostructural MOFs with a pore size of $1.3 \mathrm{~nm}$ exhibit a porefilling step near $0 \% \mathrm{RH}^{1}$

Despite the seemingly small reduction in pore diameter, a water isotherm for $\mathrm{Ni}_{2} \mathrm{Br}_{2} \mathrm{BTDD}$ material indicates that the pore-filling step shifts substantially, from $32 \% \mathrm{RH}$ at $25{ }^{\circ} \mathrm{C}$ for the $\mathrm{Cl}^{-}$and $\mathrm{F}^{-}$derivatives to $24 \% \mathrm{RH}$ for the $\mathrm{Br}^{-}$analogue (Figure $3 \mathrm{~A}$ ). As a consequence, $\mathrm{Ni}_{2} \mathrm{Br}_{2} \mathrm{BTDD}$ adsorbs a record $64 \%$ water by weight below $25 \% \mathrm{RH}$, a humidity value that is within the relevant range for many applications in heat transfer and atmospheric water capture. ${ }^{21,41}$ Notably, the total volumetric water uptake at $95 \% \mathrm{RH}$ for $\mathrm{Ni}_{2} \mathrm{Br}_{2} \mathrm{BTDD}$ (Figure $3 \mathrm{~B}$ ) is only $15 \%$ lower than that of the chloride parent material. In the very low humidity region (below $15 \% \mathrm{RH}$ ), where hydrogen bonding interactions with the framework are expected to dominate, the water uptake for $\mathrm{Ni}_{2} \mathrm{Br}_{2} \mathrm{BTDD}$ is expectedly lower than that for either the chloride or fluoride analogues, which presumably establish stronger hydrogen bonding interactions with the first water molecules entering the pores (Figure S10.1). Crucially, $\mathrm{Ni}_{2} \mathrm{Br}_{2} \mathrm{BTDD}$ maintains its porosity and crystallinity upon water cycling for at least 400 cycles (Figures 4, S3.4, and S4.4).

Infrared Spectroscopic Investigation of Hydrogen Bonding during Water Adsorption. DRIFTS under variable RH provided critical experimental evidence regarding the influence of various anions on the hydrogen bonding structure of water within each material (Figures 5 and S6.1S6.4). Four distinct regions in the water $\mathrm{O}-\mathrm{H}$ stretching regime are clearly defined in all four anion-exchanged MOFs. These four regions correspond to water molecules in differing donor-acceptor hydrogen bonding environments, which are not equivalent within the time scale of our measurement. The highest energy vibration, at $3690 \mathrm{~cm}^{-1}$, corresponds to a nearly "free" water molecule, that is, without hydrogen bonding interactions. ${ }^{42}$ This environment is assigned to water bound initially to the $\mathrm{Ni}^{2+}$ open coordination sites. The next two lower energy bands, near 3500 and $3300 \mathrm{~cm}^{-1}$, are commonly seen in IR spectra of liquid water as well as ice and are assigned to liquid-like water with one donor and one acceptor ("DA", $3545 \mathrm{~cm}^{-1}$ ) and tetrahedral, ice-like water with two donors and two acceptors ("DDAA", $3275 \mathrm{~cm}^{-1}$ ), respectively. Liquid water contains these two components at roughly a 4:3 ratio at $25{ }^{\circ} \mathrm{C} .{ }^{43,44}$ The band at 3120 is also more commonly associated with ice and is a convolution of water with one $\mathrm{H}$ atom donor and two $\mathrm{O}$ atom acceptors as well as the coupling between the $\mathrm{O}-\mathrm{H}$ stretch fundamental and the $\mathrm{HOH}$ bend overtone. $^{45}$

$\mathrm{Ni}_{2}(\mathrm{OH})_{2} \mathrm{BTDD}$ exhibits a very broad $\mathrm{O}-\mathrm{H}$ stretching region, which expands at low frequency down to $2600 \mathrm{~cm}^{-1}$ (Figure 5A). Such broad bands are commonly associated with charge transfer, ${ }^{46,47}$ presumably occurring in this case as proton transfer from adsorbed water to bridging hydroxide, to form a bridging water and a free hydroxide in the pore. We postulate that this charge transfer mechanism revealed by IR spectroscopy allows for ligand exchange and that this lability at the bridging positions results in pore collapse with the hydroxide-exchanged MOF.

In comparison with the chloride and bromide analogues, the fluoride-exchanged material exhibits a much greater signal intensity in the ice-like "DDAA" frequency region, particularly at low $\mathrm{RH}$. For instance, at $5 \% \mathrm{RH}$, the region at $3275 \mathrm{~cm}^{-1}$ is much greater in intensity than the feature at $3545 \mathrm{~cm}^{-1}$ (Figure $5 \mathrm{~B})$. As RH increases to $8 \%$, the "DDAA" region grows further, but ramping up the $\mathrm{RH}$ to $30 \%$ causes this region to decline in intensity, with concomitant emergence of the liquid-like "DA" region, which steadily increases until it is approximately equal in intensity with the "DDAA" region at $30 \% \mathrm{RH}$. The overall intensity of the whole $\mathrm{O}-\mathrm{H}$ stretching region changes little from $5 \% \mathrm{RH}$ to $30 \% \mathrm{RH}$, in agreement with the plateau in water uptake observed in this $\mathrm{RH}$ range in the water adsorption isotherm (Figure 3). From this data, we conclude that the ice-like water present at low $\mathrm{RH}$ in the $\mathrm{Ni}_{2} \mathrm{~F}_{0.83} \mathrm{Cl}_{0.17} \mathrm{BTDD}$ material does not promote further porefilling. Whereas the ice-like water has a saturated tetrahedral network of H-bonding interactions, the liquid-like "DA" water has donor and acceptor sites available to interact with further water molecules. Water in this liquid-like environment, with sites available to $\mathrm{H}$-bond with incoming water molecules, is not initially favored in the fluoride material and only grows in at higher RH.

In contrast to the fluoride-exchanged material, the liquid-like "DA" and the ice-like "DDAA" signals in $\mathrm{Ni}_{2} \mathrm{Br}_{2} \mathrm{BTDD}$ become approximately equal in intensity at much lower RH $(\sim 15 \%)$, 
whereupon the pore begins to fill (Figure 5D). In comparison, $\mathrm{Ni}_{2} \mathrm{Cl}_{2} \mathrm{BTDD}$ requires $\sim 25 \% \mathrm{RH}$ for the intensity of the liquidlike "DA" signal to exceed that of the ice-like "DDAA" water (Figure 5C). Put another way, the bromide MOF has the least rigid hydrogen bonding network at low relative humidity. The emerging fundamental insight is that, in order for the pore to fill with water, there must be a sufficient concentration of water molecules with unsaturated hydrogen bonding environments to attract more water. These data implicate the hydrogenbonding interface between water initially adsorbed at strong binding sites and incoming water in the center of the pore as a determining factor in the thermodynamic favorability of porefilling at a given RH. The importance of this interfacial watercentral water interface versus the interface between the pore wall and the interfacial water was not previously understood and may be related to the reduction in pore diameter below the "critical diameter" prior to the pore-filling step by preadsorbed water, which makes the water adsorption process in these materials reversible and without hysteresis. ${ }^{2}$

Potential Utility of $\mathrm{Ni}_{2} \mathrm{Cl}_{2} \mathrm{BTDD}$ and $\mathrm{Ni}_{2} \mathrm{Br}_{2} \mathrm{BTDD}$ in Applications Involving Water Sorption. Water cycling experiments for $\mathrm{Ni}_{2}(\mathrm{OH})_{2} \mathrm{BTDD}$ and $\mathrm{Ni}_{2} \mathrm{~F}_{0.83} \mathrm{Cl}_{0.17} \mathrm{BTDD}$ revealed steep declines in capacity with repeated cycling (Figures S7.1 and S7.2). In contrast, $\mathrm{Ni}_{2} \mathrm{Br}_{2} \mathrm{BTDD}$ appears to be essentially indefinitely stable, maintaining its crystallinity (Figure S3.5) and its initial water capacity of $65 \mathrm{wt} \%$ after 400 cycles (Figure 4), similar to the parent chloride material. The superlative stability of $\mathrm{Ni}_{2} \mathrm{Cl}_{2} \mathrm{BTDD}$ and $\mathrm{Ni}_{2} \mathrm{Br}_{2} \mathrm{BTDD}$ prompted us to further investigate these materials for applications in heat transfer. Variable temperature water isotherms (Figure 6A) were employed to confirm the applicability of a characteristic curve (Figure 6B), which converts the two independent variables governing uptake (temperature and pressure) into a single parameter, $A$, related to the Gibbs free energy. ${ }^{3,5,21}$ On the basis of the overlapping positions of the uptake step in the characteristic curve, this method can be used to calculate loadings at other temperatures and pressures relevant for heat transfer applications. Using the variable temperature water isotherms, the heat of adsorption for water in both chloride and bromide derivatives is approximately $-57 \mathrm{~kJ} \mathrm{~mol}^{-1}$ at zero coverage (Figure S10.2). On the basis of the characteristic curve, for applications in heat transfer, the $\mathrm{Cl}^{-}$material can achieve a $19^{\circ} \mathrm{C}$ temperature lift (the temperature difference between the environment and the output of a heat pump), with a requirement for thermal regeneration at approximately $53{ }^{\circ} \mathrm{C}$. In contrast, the $\mathrm{Br}^{-}$ material can achieve a $24{ }^{\circ} \mathrm{C}$ temperature lift and requires heating to $58{ }^{\circ} \mathrm{C}$ for regeneration. To our knowledge, each of these materials exhibits a record water capacity, measured either volumetrically or gravimetrically, compared to sorbents capable of equivalent respective temperature lifts (Tables 2 and 3).

\section{CONCLUSIONS}

$\mathrm{Ni}_{2} \mathrm{Cl}_{2} \mathrm{BTDD}$ is a strong candidate for water sorption applications, with a record reversible water uptake below $32 \%$ relative humidity. Because of the inertness of $\mathrm{Ni}^{2+}$, it exhibits exceptional stability toward water cycling, in excess of that previously reported for the analogous $\mathrm{Co}^{2+}$ material. Introduction of anions with greater potential for hydrogen bonding interactions, such as $\mathrm{F}^{-}$or $\mathrm{OH}^{-}$, did not lead to shifts in the water uptake step profile toward lower $\mathrm{RH}$, though these anions did promote increased water adsorption at very low
Table 2. Water Capacities for Selected Porous Materials with $\alpha$ at or below $25 \% \mathrm{RH}$

\begin{tabular}{lcccc} 
& $\begin{array}{c}\alpha^{a} \\
(\% \mathrm{RH})\end{array}$ & $\begin{array}{c}\text { uptake } \\
\left(\mathrm{g} \mathrm{g}^{-1}\right)\end{array}$ & $\begin{array}{c}\text { crystal } \rho \\
\left(\mathrm{g} \mathrm{cm}^{-3}\right)\end{array}$ & $\begin{array}{c}\text { uptake } \\
\left(\mathrm{cm}^{3} \mathrm{~cm}^{-3}\right)\end{array}$ \\
AQSOA Z01 $^{21}$ & 17 & 0.18 & 1.75 & 0.315 \\
AQSOA Z05 $^{21}$ & 25 & 0.18 & 1.75 & 0.315 \\
MIL-160 & 8 & 0.37 & 1.15 & 0.426 \\
AQSOA Z02 $^{21}$ & 8 & 0.3 & 1.43 & 0.429 \\
CAU-10 $^{48}$ & 18 & 0.38 & 1.15 & 0.437 \\
Ni $_{2} \mathrm{Cl}_{2} \mathrm{BBTA}^{1}$ & 3 & 0.4 & 1.1 & 0.44 \\
MOF-801 $^{10}$ & 9 & 0.28 & 1.59 & 0.445 \\
Ti-MIL-125-NH $_{2}{ }^{49}$ & 23 & 0.68 & 0.757 & 0.515 \\
MIP-200 $^{4}$ & 18 & 0.45 & 1.16 & 0.522 \\
MOF-841 $^{10}$ & 22 & 0.51 & 1.05 & 0.536 \\
ALPO-78 $^{50}$ & 18 & 0.32 & 1.7 & 0.544 \\
MOF-303 $^{13}$ & 15 & 0.48 & 1.159 & 0.556 \\
Ni $_{2} \mathrm{Br}_{2} \mathrm{BTDD}^{b}$ & 24 & 0.76 & 0.764 & 0.581 \\
\hline is & &
\end{tabular}

${ }^{a} \alpha$ is the $\% \mathrm{RH}$ at which half of the total uptake at $95 \% \mathrm{RH}$ is reached. ${ }^{b}$ This work.

Table 3. Water Capacities for Selected Porous Materials with $\alpha$ at or below $35 \% \mathrm{RH}$

\begin{tabular}{|c|c|c|c|c|}
\hline & $\begin{array}{c}\alpha^{a} \\
(\% \mathrm{RH})\end{array}$ & $\begin{array}{l}\text { uptake } \\
\left(\mathrm{g} \mathrm{g}^{-1}\right)\end{array}$ & $\begin{array}{l}\text { crystal } \rho \\
\left(\mathrm{g} \mathrm{cm}^{-3}\right)\end{array}$ & $\begin{array}{c}\text { uptake } \\
\left(\mathrm{cm}^{3} \mathrm{~cm}^{-3}\right)\end{array}$ \\
\hline $\mathrm{UiO}-66^{21}$ & 34 & 0.43 & 1.24 & 0.533 \\
\hline Al fumarate ${ }^{21}$ & 28 & 0.45 & 1.24 & 0.558 \\
\hline $\mathrm{Co}_{2} \mathrm{Cl}_{2} \mathrm{BTDD}^{2}$ & 29 & 0.97 & 0.65 & 0.631 \\
\hline $\mathrm{Ni}_{2} \mathrm{Cl}_{2} \mathrm{BTDD}^{b}$ & 32 & 1.07 & 0.64 & 0.685 \\
\hline
\end{tabular}

${ }^{a} \alpha$ is the $\% \mathrm{RH}$ at which half of the total uptake at $95 \% \mathrm{RH}$ is reached.

$b_{\text {This work. }}$

$\mathrm{RH}$. These results indicate that, as long as nucleation sites exist for water, further increasing the pore wall hydrophilicity does not change the position of the water uptake step. Contraction of the accessible pore diameter by just $0.1 \mathrm{~nm}$ as well as modification of the polarity of initially adsorbed $\mathrm{H}_{2} \mathrm{O}$ by the introduction of $\mathrm{Br}^{-}$results in a pore-filling step at lower $\mathrm{RH}$ by $8 \%$. The resulting $\mathrm{Ni}_{2} \mathrm{Br}_{2} \mathrm{BTDD}$ material has the greatest capacity, measured gravimetrically or volumetrically, of any material below $25 \% \mathrm{RH}$. The capacity of $0.64 \mathrm{~g}$ of water per $\mathrm{g}^{-1}$ of MOF achieved below $25 \% \mathrm{RH}$ is a new record in this partial pressure region relevant for many applications in heat transfer and atmospheric water generation, which represents a large leap forward achieved via precise pore size control and polarity modification not possible in other materials.

\section{ASSOCIATED CONTENT}

Supporting Information

The Supporting Information is available free of charge on the ACS Publications website at DOI: 10.1021/jacs.9b06246.

Experimental and computational procedures, synthetic methods, materials characterization, structural refinement information, and Figures S3.1-S10.2 (PDF)

\section{AUTHOR INFORMATION}

\section{Corresponding Author}

*E-mail: mdinca@mit.edu.

ORCID

Adam J. Rieth: 0000-0002-9890-1346

Ashley M. Wright: 0000-0002-9475-2638

Christopher H. Hendon: 0000-0002-7132-768X 
Mircea Dincă: 0000-0002-1262-1264

\section{Notes}

The authors declare the following competing financial interest(s): A.J.R. and M.D. are inventors on a patent pertaining to the materials discussed herein.

\section{ACKNOWLEDGMENTS}

Fundamental studies of small molecule interactions with MOFs are supported by the National Science Foundation through a CAREER Award to M.D. (DMR-1452612). A.J.R. is supported by the Martin Family Fellowship for Sustainability. Funding for water capture comes from the Abdul Latif Jameel Water and Food Systems Lab (J-WAFS). Use of the Advanced Photon Source at Argonne National Laboratory was supported by the U.S. Department of Energy, Office of Science, Office of Basic Energy Sciences, under Contract No. DE-AC0206CH11357. This work made use of the Shared Experimental Facilities supported in part by the MRSEC Program of the National Science Foundation under award number DMR1419807. This work used the Extreme Science and Engineering Discovery Environment (XSEDE), which is supported by National Science Foundation grant number ACI-1548562. We thank Dr. Robert W. Day for assistance with acquiring XPS data.

\section{REFERENCES}

(1) Rieth, A. J.; Wright, A. M.; Rao, S.; Kim, H.; LaPotin, A. D.; Wang, E. N.; Dincă, M. Tunable Metal-Organic Frameworks Enable High-Efficiency Cascaded Adsorption Heat Pumps. J. Am. Chem. Soc. 2018, 140 (50), 17591-17596.

(2) Rieth, A. J.; Yang, S.; Wang, E. N.; Dincă, M. Record Atmospheric Fresh Water Capture and Heat Transfer with a Material Operating at the Water Uptake Reversibility Limit. ACS Cent. Sci. 2017, 3 (6), 668-672.

(3) de Lange, M. F.; van Velzen, B. L.; Ottevanger, C. P.; Verouden, K. J. F. M.; Lin, L.-C.; Vlugt, T. J. H.; Gascon, J.; Kapteijn, F. MetalOrganic Frameworks in Adsorption-Driven Heat Pumps: The Potential of Alcohols as Working Fluids. Langmuir 2015, 31 (46), 12783-12796.

(4) Wang, S.; Lee, J. S.; Wahiduzzaman, M.; Park, J.; Muschi, M.; Martineau-Corcos, C.; Tissot, A.; Cho, K. H.; Marrot, J.; Shepard, W.; Maurin, G.; Chang, J.; Serre, C. A Robust Large-Pore Zirconium Carboxylate Metal-Organic Framework for Energy-Efficient WaterSorption-Driven Refrigeration. Nat. Energy 2018, 3 (11), 985-993.

(5) Cadiau, A.; Lee, J. S.; Damasceno Borges, D.; Fabry, P.; Devic, T.; Wharmby, M. T.; Martineau, C.; Foucher, D.; Taulelle, F.; Jun, C. H.; Hwang, Y. K.; Stock, N.; De Lange, M. F.; Kapteijn, F.; Gascon, J.; Maurin, G.; Chang, J. S.; Serre, C. Design of Hydrophilic Metal Organic Framework Water Adsorbents for Heat Reallocation. Adv. Mater. 2015, 27 (32), 4775-4780.

(6) Khutia, A.; Rammelberg, H. U.; Schmidt, T.; Henninger, S.; Janiak, C. Water Sorption Cycle Measurements on Functionalized MIL-101Cr for Heat Transformation Application. Chem. Mater. 2013, 25 (5), 790-798.

(7) Jeremias, F.; Khutia, A.; Henninger, S. K.; Janiak, C. MIL$100(\mathrm{Al}, \mathrm{Fe})$ as Water Adsorbents for Heat Transformation Purposes-a Promising Application. J. Mater. Chem. 2012, 22 (20), 10148.

(8) Kummer, H.; Jeremias, F.; Warlo, A.; Füldner, G.; Fröhlich, D.; Janiak, C.; Gläser, R.; Henninger, S. K. A Functional Full-Scale Heat Exchanger Coated with Aluminum Fumarate Metal-Organic Framework for Adsorption Heat Transformation. Ind. Eng. Chem. Res. 2017, 56 (29), 8393-8398.

(9) Kim, H.; Yang, S.; Rao, S. R.; Narayanan, S.; Kapustin, E. A.; Furukawa, H.; Umans, A. S.; Yaghi, O. M.; Wang, E. N. Water
Harvesting from Air with Metal-Organic Frameworks Powered by Natural Sunlight. Science 2017, 356 (6336), 430-434.

(10) Furukawa, H.; Gándara, F.; Zhang, Y.-B.; Jiang, J.; Queen, W. L.; Hudson, M. R.; Yaghi, O. M. Water Adsorption in Porous MetalOrganic Frameworks and Related Materials. J. Am. Chem. Soc. 2014, 136 (11), 4369-4381.

(11) Kalmutzki, M. J.; Diercks, C. S.; Yaghi, O. M. Metal-Organic Frameworks for Water Harvesting from Air. Adv. Mater. 2018, 30 (37), 1704304.

(12) Kim, H.; Rao, S. R.; Kapustin, E. A.; Zhao, L.; Yang, S.; Yaghi, O. M.; Wang, E. N. Adsorption-Based Atmospheric Water Harvesting Device for Arid Climates. Nat. Commun. 2018, 9 (1), 1191.

(13) Fathieh, F.; Kalmutzki, M. J.; Kapustin, E. A.; Waller, P. J.; Yang, J.; Yaghi, O. M. Practical Water Production from Desert Air. Sci. Adv. 2018, 4 (6), eaat 3198.

(14) Cui, S.; Qin, M.; Marandi, A.; Steggles, V.; Wang, S.; Feng, X.; Nouar, F.; Serre, C. Metal-Organic Frameworks as Advanced Moisture Sorbents for Energy-Efficient High Temperature Cooling. Sci. Rep. 2018, 8 (1), 15284.

(15) Towsif Abtab, S. M.; Alezi, D.; Bhatt, P. M.; Shkurenko, A.; Belmabkhout, Y.; Aggarwal, H.; Weseliński, Ł. J.; Alsadun, N.; Samin, U.; Hedhili, M. N.; Eddaoudi, M. Reticular Chemistry in Action: A Hydrolytically Stable MOF Capturing Twice Its Weight in Adsorbed Water. Chem. 2018, 4 (1), 94-105.

(16) Chen, Z.; Li, P.; Zhang, X.; Li, P.; Wasson, M. C.; Islamoglu, T.; Stoddart, J. F.; Farha, O. K. Reticular Access to Highly Porous Acs -MOFs with Rigid Trigonal Prismatic Linkers for Water Sorption. J. Am. Chem. Soc. 2019, 141 (7), 2900-2905.

(17) Abdulhalim, R. G.; Bhatt, P. M.; Belmabkhout, Y.; Shkurenko, A.; Adil, K.; Barbour, L. J.; Eddaoudi, M. A Fine-Tuned MetalOrganic Framework for Autonomous Indoor Moisture Control. J. Am. Chem. Soc. 2017, 139 (31), 10715-10722.

(18) Seo, Y.-K.; Yoon, J. W.; Lee, J. S.; Hwang, Y. K.; Jun, C.-H.; Chang, J.-S.; Wuttke, S.; Bazin, P.; Vimont, A.; Daturi, M.; Bourrelly, S.; Llewellyn, P. L.; Horcajada, P.; Serre, C.; Férey, G. EnergyEfficient Dehumidification over Hierachically Porous Metal-Organic Frameworks as Advanced Water Adsorbents. Adv. Mater. 2012, 24 (6), 806-810.

(19) Ceriotti, M.; Fang, W.; Kusalik, P. G.; McKenzie, R. H.; Michaelides, A.; Morales, M. A.; Markland, T. E. Nuclear Quantum Effects in Water and Aqueous Systems: Experiment, Theory, and Current Challenges. Chem. Rev. 2016, 116 (13), 7529-7550.

(20) Cisneros, G. A.; Wikfeldt, K. T.; Ojamäe, L.; Lu, J.; Xu, Y.; Torabifard, H.; Bartók, A. P.; Csányi, G.; Molinero, V.; Paesani, F. Modeling Molecular Interactions in Water: From Pairwise to ManyBody Potential Energy Functions. Chem. Rev. 2016, 116 (13), 75017528.

(21) De Lange, M. F.; Verouden, K. J. F. M.; Vlugt, T. J. H.; Gascon, J.; Kapteijn, F. Adsorption-Driven Heat Pumps: The Potential of Metal-Organic Frameworks. Chem. Rev. 2015, 115 (22), 1220512250.

(22) Wright, A. M.; Rieth, A. J.; Yang, S.; Wang, E.; Dinca, M. Precise Control of Pore Hydrophilicity Enabled by Post-Synthetic Cation Exchange in Metal-Organic Frameworks. Chem. Sci. 2018, 9, 3856.

(23) Wade, C. R.; Corrales-Sanchez, T.; Narayan, T. C.; Dincă, M. Postsynthetic Tuning of Hydrophilicity in Pyrazolate MOFs to Modulate Water Adsorption Properties. Energy Environ. Sci. 2013, 6 (7), 2172

(24) Akiyama, G.; Matsuda, R.; Sato, H.; Hori, A.; Takata, M.; Kitagawa, S. Effect of Functional Groups in MIL-101 on Water Sorption Behavior. Microporous Mesoporous Mater. 2012, 157, 89-93.

(25) Canivet, J.; Bonnefoy, J.; Daniel, C.; Legrand, A.; Coasne, B.; Farrusseng, D. Structure-Property Relationships of Water Adsorption in Metal-Organic Frameworks. New J. Chem. 2014, 38 (7), 3102.

(26) Douss, N.; Meunier, F. Experimental Study of Cascading Adsorption Cycles. Chem. Eng. Sci. 1989, 44 (2), 225-235. 
(27) Critoph, R. E. Evaluation of Alternative Refrigerant-Adsorbent Pairs for Refrigeration Cycles. Appl. Therm. Eng. 1996, 16 (11), 891900.

(28) Padial, N. M.; Quartapelle Procopio, E.; Montoro, C.; López, E.; Oltra, J. E.; Colombo, V.; Maspero, A.; Masciocchi, N.; Galli, S.; Senkovska, I.; Kaskel, S.; Barea, E.; Navarro, J. A. R. Highly Hydrophobic Isoreticular Porous Metal-Organic Frameworks for the Capture of Harmful Volatile Organic Compounds. Angew. Chem., Int. Ed. 2013, 52 (32), 8290-8294.

(29) Zhang, Y. Z.; He, T.; Kong, X. J.; Lv, X. L.; Wu, X. Q.; Li, J. R. Tuning Water Sorption in Highly Stable $\mathrm{Zr}(\mathrm{IV})$-Metal-Organic Frameworks through Local Functionalization of Metal Clusters. ACS Appl. Mater. Interfaces 2018, 10 (33), 27868-27874.

(30) Davis, J. G.; Gierszal, K. P.; Wang, P.; Ben-Amotz, D. Water Structural Transformation at Molecular Hydrophobic Interfaces. Nature 2012, 491 (7425), 582-585.

(31) Koga, K.; Gao, G. T.; Tanaka, H.; Zeng, X. C. Formation of Ordered Ice Nanotubes inside Carbon Nanotubes. Nature 2001, 412 (6849), 802-805.

(32) Furukawa, H.; Cordova, K. E.; O’Keeffe, M.; Yaghi, O. M. The Chemistry and Applications of Metal-Organic Frameworks. Science 2013, 341 (6149), 1230444-1230444.

(33) LaPotin, A.; Kim, H.; Rao, S. R.; Wang, E. N. Adsorption-Based Atmospheric Water Harvesting: Impact of Material and Component Properties on System-Level Performance. Acc. Chem. Res. 2019, 52 (6), 1588-1597.

(34) Coasne, B.; Gubbins, K. E.; Pellenq, R. J. M. Temperature Effect on Adsorption/Desorption Isotherms for a Simple Fluid Confined within Various Nanopores. Adsorption 2005, 11, 289-294.

(35) Eigen, M. Fast Elementary Steps in Chemical Reaction Mechanisms. Pure Appl. Chem. 1963, 6, 97-115.

(36) Rieth, A. J.; Tulchinsky, Y.; Dincă, M. High and Reversible Ammonia Uptake in Mesoporous Azolate Metal-Organic Frameworks with Open Mn, Co, and Ni Sites. J. Am. Chem. Soc. 2016, 138 (30), 9401-9404.

(37) Rieth, A. J.; Dincă, M. Controlled Gas Uptake in Metal-Organic Frameworks with Record Ammonia Sorption. J. Am. Chem. Soc. 2018, 140 (9), 3461-3466.

(38) Wang, Y.; Huang, N. Y.; Shen, J. Q.; Liao, P. Q.; Chen, X. M.; Zhang, J. P. Hydroxide Ligands Cooperate with Catalytic Centers in Metal-Organic Frameworks for Efficient Photocatalytic CO2 Reduction. J. Am. Chem. Soc. 2018, 140 (1), 38-41.

(39) Barrett, E. P.; Joyner, L. G.; Halenda, P. P. The Determination of Pore Volume and Area Distributions in Porous Substances. I. Computations from Nitrogen Isotherms. J. Am. Chem. Soc. 1951, 73 (1), 373-380.

(40) Kruk, M.; Jaroniec, M.; Sayari, A. Application of Large Pore MCM-41 Molecular Sieves To Improve Pore Size Analysis Using Nitrogen Adsorption Measurements. Langmuir 1997, 13 (23), 62676273.

(41) Lenzen, D.; Bendix, P.; Reinsch, H.; Fröhlich, D.; Kummer, H.; Möllers, M.; Hügenell, P. P. C.; Gläser, R.; Henninger, S.; Stock, N.; Kalmutzki, M. J.; Diercks, C. S.; Yaghi, O. M. Metal-Organic Frameworks for Water Harvesting from Air. Adv. Mater. 2018, 30 (37), 1704304.

(42) Dalla Bernardina, S.; Paineau, E.; Brubach, J.-B.; Judeinstein, P.; Rouzière, S.; Launois, P.; Roy, P. Water in Carbon Nanotubes: The Peculiar Hydrogen Bond Network Revealed by Infrared Spectroscopy. J. Am. Chem. Soc. 2016, 138 (33), 10437-10443.

(43) Choe, C.; Lademann, J.; Darvin, M. E. Depth Profiles of Hydrogen Bound Water Molecule Types and Their Relation to Lipid and Protein Interaction in the Human Stratum Corneum: In Vivo. Analyst 2016, 141 (22), 6329-6337.

(44) Byl, O.; Liu, J. C.; Wang, Y.; Yim, W. L.; Johnson, J. K.; Yates, J. T. Unusual Hydrogen Bonding in Water-Filled Carbon Nanotubes. J. Am. Chem. Soc. 2006, 128 (37), 12090-12097.

(45) Hunter, K. M.; Shakib, F. A.; Paesani, F. Disentangling Coupling Effects in the Infrared Spectra of Liquid Water. J. Phys. Chem. B 2018, 122 (47), 10754-10761.
(46) Katada, M.; Fujii, A. Infrared Spectroscopy of Protonated Phenol-Water Clusters. J. Phys. Chem. A 2018, 122, 5822-5831.

(47) Borges, D. D.; Semino, R.; Devautour-Vinot, S.; Jobic, H.; Paesani, F.; Maurin, G. Computational Exploration of the Water Concentration Dependence of the Proton Transport in the Porous UiO-66(Zr)-(CO2H)2 Metal-Organic Framework. Chem. Mater. 2017, 29 (4), 1569-1576.

(48) Fröhlich, D.; Pantatosaki, E.; Kolokathis, P. D.; Markey, K.; Reinsch, H.; Baumgartner, M.; Van Der Veen, M. A.; De Vos, D. E.; Stock, N.; Papadopoulos, G. K.; Henninger, S. K.; Janiak, C. Water Adsorption Behaviour of CAU-10-H: A Thorough Investigation of Its Structure-Property Relationships. J. Mater. Chem. A 2016, 4 (30), 11859-11869.

(49) Sohail, M.; Yun, Y. N.; Lee, E.; Kim, S. K.; Cho, K.; Kim, J. N.; Kim, T. W.; Moon, J. H.; Kim, H. Synthesis of Highly Crystalline NH2-MIL-125 (Ti) with S-Shaped Water Isotherms for Adsorption Heat Transformation. Cryst. Growth Des. 2017, 17 (3), 1208-1213.

(50) Yuhas, B. D.; Mowat, J. P. S.; Miller, M. A.; Sinkler, W. AlPO78: A 24-Layer ABC-6 Aluminophosphate Synthesized Using a Simple Structure-Directing Agent. Chem. Mater. 2018, 30 (3), 582586. 